University of Michigan Law School

University of Michigan Law School Scholarship Repository

\title{
Supervising Outsourcing: The Need for Better Design of Blended Governance
}

\author{
Nina A. Mendelson \\ University of Michigan Law School, nmendel@umich.edu
}

Available at: https://repository.law.umich.edu/book_chapters/161

Follow this and additional works at: https://repository.law.umich.edu/book_chapters

Part of the Administrative Law Commons, Government Contracts Commons, and the Rule of Law Commons

\section{Publication Information \& Recommended Citation}

Mendelson, Nina A. "Supervising Outsourcing: The Need for Better Design of Blended Governance." In Administrative Law from the Inside Out: Essays on Themes in the Work of Jerry L. Mashaw, edited by Nicholas R. Parrillo, 427-450. Cambridge: Cambridge University Press, 2017.

This Book Chapter is brought to you for free and open access by the Faculty Scholarship at University of Michigan Law School Scholarship Repository. It has been accepted for inclusion in Book Chapters by an authorized administrator of University of Michigan Law School Scholarship Repository. For more information, please contact mlaw.repository@umich.edu. 


\title{
Supervising Outsourcing
}

\section{The Need for Better Design of Blended Governance}

\author{
Nina A. Mendelson*
}

\section{INTRODUCTION}

We are long past the "vending machine"-style privatization of government functions - where the government contracts to buy a discrete product or service at a set price, whether aircraft components or landscaping. ${ }^{1}$ Government is increasingly enlisting, or collaborating with, private entities for functions long perceived as distinctly public. Private entities may make policy explicitly (through standards that agencies later adopt) or implicitly (through the thirdparty verification of compliance with regulatory objectives). For example, the Department of Health and Human Services relies on the recommendations of an American Medical Association committee of specialist physicians to establish Medicare physician payments, while the US Department of Agriculture relies on private and state organizations to certify that food meets federal organic standards. ${ }^{2}$ Not only do these appear to be public functions, and important ones, but private actors also are exercising considerable discretion and sophisticated judgment in carrying them out. ${ }^{3}$ Meanwhile, as

* Particular thanks for valuable discussion and comments go to Nick Bagley, Rebecca Eisenberg, Riyaz Kanji, Jerry L. Mashaw, Nick Parrillo, participants in the University of Michigan Student Scholarship Workshop, and participants in "Administrative Law from the Inside Out: A Conference on Themes in the Work of Jerry L. Mashaw" at the Yale Law School. I am also grateful to the University of Michigan Law School's Cook Fund for research support.

1 Donald Kettl, Managing Indirect Government, in Tools of Government 490, 494 (Lester Salamon ed., 2002) ("vending machine").

2 See infra text accompanying notes 90-91.

3 William J. Novak, Public-Private Governance: A Historical Introduction, in Government By Contract 23 (Jody Freeman \& Martha Minow eds., 2009); see generally Jody Freeman, Extending Public Law Norms through Privatization, 116 Harv. L. Rev. 1285, 1289 (2003) ("There is ... a discernible trend toward 'privatization'...."). Such practices do have antecedents. E.g., Novak, supra, at 27-28 (discussing private or mixed public-private institutional control over subjects ranging from "public order to the construction and management of roads and public 
the examples suggest, many of these outsourcing relationships are far from the fairly structured principal-agent relationship that characterizes traditional outsourcing by contract.

Private efforts can, of course, contribute expertise to the government enterprise - often substantial expertise - as well as efficiency resulting from market discipline. Private efforts also can present distinct risks, including abuse of discretion, "fraud, mismanagement, cost overruns - and lack of transparency to the public" or other overseers. ${ }^{4} \mathrm{Or}$, as in the case of food certifiers, conflicts stemming from payment of the inspectors by the inspected.

The typical assumption: we can avoid privatization's troubles by relying on the public-interested agency official to keep an eye on things. The official could override a private decision here, revoke an accreditation there, decline to use a private standard or recommendation in federal law, or simply monitor private activity. 5 The assumption is that proper supervision mainly requires sufficient resources. ${ }^{6}$

Especially for outsourcing that looks so little like traditional notions of government contracting, however, an agency supervisor may face significant hindrances. The supervising agency may be plagued by inadequate expertise and information; pressure, inside and outside the agency, to go easy on the private entity, combined with the temptation to claim credit for addressing the underlying problem; as well as other less-than-ideal motivations. Meanwhile, procedures that might otherwise inform and constrain agency decision-making may be poorly suited to supervision of outsourcing. My focus here is mainly upon the outsourcing relationships outside the government contracting framework. Although there are important parallels to the problem I discuss here, a considerable literature already focuses upon agency monitoring of government contracts. ${ }^{7}$

It seems particularly appropriate to explore these issues in a symposium to honor Professor Jerry L. Mashaw, given his incalculable contributions to the field's thinking on institutional design, accountability, and privatization.

works”); David A. Sklansky, The Private Police, 46 UCLA L. REv. 1165 (1999) (discussing private "policing" in early America and elsewhere).

4 Martha Minow, Outsourcing Power, in Government by Contract 110, 113 (Jody Freeman \& Martha Minow eds., 2009); see infra Section II.B.

5 Paul Posner, Accountability Challenges of Third-Party Government, in Tools of Government 523, 539 (Lester Salamon ed., 2002).

${ }^{6}$ See infra note 68 (quoting numerous sources focusing on resource needs of supervising agencies).

7 E.g., Steven Kelman, Achieving Contracting Goals and Recognizing Public Law Concerns, in Government by Contract, 153, 154-91 (Jody Freeman \& Martha Minow eds., 2009); Minow, supra note 4 , at 116-17. 
Regarding privatization, Mashaw has urged greater attention to accountability in context, including consideration of the relations among particular affected parties, ${ }^{8}$ an insight especially pertinent to assessing agency oversight.

The point here: we cannot readily assume that an agency official's simple presence will suffice to avoid privatization's dysfunctions and to supply public accountability. 9 More careful attention to how agencies supervise outsourcing - and how they should conduct such oversight - is clearly needed. In this essay, I attempt to lay out some obstacles to effective supervision and then follow with some preliminary considerations for reform.

\section{DISCUSSION}

\section{A Outsourcing in the Realm of Policy}

The outsourcing of functions traditionally allocated to governmental entities is endemic in the modern regulatory state. Administrative law scholars sometimes describe it as the "privatized state," 10 "harnessing," "public-private governance,"12 a "public-private partnership,"13 or "collaboration."14 When agency supervision is easy, we often prefer private performance of public functions that can be both well-specified, ex ante, and more efficiently performed by private entities disciplined by market forces. ${ }^{15}$ Food service to the troops, contracted out after a bidding process, seems a good example.

But outsourcing now extends far beyond the bounds of such easily supervised, specified practices. The increasingly formalized private role in formulating standards and devising policy seems to defy policies such as Office of Management and Budget ("OMB") Circular A-76. That document, which by its terms governs only contracting, articulates a policy of relying "on the private sector for needed commercial services," while instructing agencies to reserve "inherently governmental activities" for performance by government

8 Jerry L. Mashaw, Accountability and Institutional Design: Some Thoughts on the Grammar of Governance, in Public Accountability: Designs, Dilemmas, and Experiences 115 (Michael Dowdle ed., 2006).

9 See infra note 68 (citing numerous sources).

10 Jon Michaels, An Enduring, Evolving Separation of Powers, 115 Colum. L. Rev. 515 (2015).

${ }_{11}$ Lesley McAllister, Harnessing Private Regulation, 3 Mich. J. Envtl. \& Admin. L. 291 (2014).

12 Novak, supra note 3, at 23.

13 Martha Minow, Partners, Not Rivals: Privatization and the Public Good (2003).

14 See also Steven Schooner, Contractor Atrocities at Abu Ghraib, 16 Stan. L. \& Pol’y Rev. 549, 553 (2005) ("competitive sourcing").

15 Of course, the prospect of market discipline for contractors sometimes may prove illusory, as when a contractor supplying goods is paid for cost overruns. 
personnel. ${ }^{16}$ The Federal Acquisition Regulation ("FAR") classifies "[t]he determination of agency policy, such as determining the content and application of regulations" as inherently governmental. ${ }^{17}$

Yet many arrangements, encompassing an extraordinarily wide array of subject areas, seem to cross this apparent boundary into inherently governmental activities. Government contracting of sophisticated services over a long period of time may seem an obvious example of boundary-crossing, including privatization of prison management or security services. ${ }^{8}$ Those functions, which are performed under contract, strike us as a traditional state function; meanwhile their implementation necessarily involves significant policy-setting.

Other outsourcing arrangements are far less structured than contracting. Agencies use third-party programs to assess regulatory compliance with standards, such as for energy and water use efficiency ${ }^{19}$ or greenhouse gas emissions. ${ }^{20}$ As the legislative history authorizing the US Department of Agriculture to utilize private and state organizations to certify foods as compliant with federal organic standards explains, this program was to "take advantage of the network of existing entities already engaged in certification." ${ }^{21}$ Such entities necessarily must resolve policy questions not definitively settled by the regulatory standards themselves.

Agency reliance upon self-regulatory or combined public-private entities represents another outsourcing of policymaking outside the traditional

16 Office of Mgmt. \& Budget, Exec. Office of the President, OMB Circular No. A-76 (revised May 29, 2003).

17 FAR $\$ 7.503$ (c)(5) (2016) ("determination of agency policy"). Services that "relate to the development of regulations," however, are not classified as "inherently governmental." FAR $\mathbb{} 7.503(\mathrm{~d})(4)$ (2016) ("development of regulations").

18 See also John Donahue, The Transformation of Government Work, in Government By ConTRACT 41, 56 (Jody Freeman \& Martha Minow eds., 2009) (noting contracting out of "investigat[ing] charges of malfeasance against several other federal contractors"); Kelman, supra note 7, at 177 (noting EPA contractors' "drafting budget documents ... [and] regulation preambles, and organizing ... public hearings").

19 See Admin. Conference of the US, Recommendation 2012-7, Agency Use of Third-Party Programs to Assess Regulatory Compliance (Dec. 6, 2012), http://www .acus.gov/sites/default/files/documents/Recommendation\%202012-7\%20\%28Third-Party\%20 Programs\%zoto\%2oAssess\%zoRegulatory\%zoCompliance\%29.pdf. Office of Management and Budget policy is to encourage agencies to utilize pre-existing "private sector conformity assessment activities." See Office of Mgmt. \& Budget, Exec. Office of the President, OMB Circular No. A-119, 7 (revised 2016) ("What is the Policy on Conformity Assessment?").

20 E.g., Lesley K. McAllister, Regulation by Third-Party Verification, 53 B.C. L. Rev. 1, 2930 (arguing that compliance is fluid and not necessarily obvious: "Determining whether a regulated entity is in compliance involves the exercise of a great deal of discretion").

${ }^{21}$ S. Rep. No. 101-357, at 4948 (1990). 
contracting framework. ${ }^{22}$ For example, the Public Company Accounting Oversight Board (PCAOB), created by the Sarbanes-Oxley Act of 2002, issues rules for the accounting industry, subject to Securities and Exchange Commission (SEC) approval. ${ }^{23}$ The securities industry has long been regulated in significant part by industry self-regulatory organizations, also overseen by the SEC. 24

Congress sometimes specifies such arrangements, but often it is an agency that enlists a private organization in performing public functions, such as standard-setting or inspection. ${ }^{25}$ Agencies often choose to utilize privately drafted standards as federal rules, including a phenomenon I have discussed elsewhere, known as "incorporation by reference." ${ }^{26}$ The Departments of Labor, Transportation, Interior, and other agencies have incorporated by reference numerous privately drafted standards for manufacturing and safety, including OSHA worker safety standards for workers who feed scrap paper to balers, ${ }^{27}$ and Interior Department standards for oil and gas drilling platforms in the Outer Continental Shelf. ${ }^{28}$ Preparing such standards often requires decision-making under scientific uncertainty, which can shift even ostensibly neutral "technical" standards into the policy realm. ${ }^{29}$

Outsourcing can offer an agency (and the public) important advantages, such as technical expertise and, potentially, the promise of greater efficiency. $3^{\circ}$

22 Anne O'Connell, Bureaucracy at the Boundary, 162 U. Penn. L. Rev. 841, 856-61 (2014) (noting the existence of numerous entities at the government-private border).

23 The PCAOB was created "to oversee the audit of public companies that are subject to the securities laws." 15 USC \& 7211(a) (2012); see also Patricia Bellia, PCAOB and the Persistence of the Removal Puzzle, 80 GeO. WASH. L. Rev. 1371, 1400-05 (2012).

24 E.g., US Gov't Accountability Office, GAO-15-376, SEC Oversight of FiNRA 1 (2015) ("SEC oversees SROs to ensure that they carry out their regulatory responsibilities.").

25 As noted, this paper does not focus upon oversight of government contracts. Nor does this paper focus upon self-regulation, private action that may fill a gap in governance.

26 See generally Nina Mendelson, Private Control over Access to the Law: The Perplexing Federal Regulatory Use of Private Standards, 112 Мich. L. Rev. 737 (2014); Paul Verkuil, Outsourcing and the Duty to Govern, in Government by Contract 310, 313 (Jody Freeman \& Martha Minow eds., 2009) (noting that policymaking functions are "increasingly delegated to private hands").

27 See, e.g., 29 CFR $\$ 570.63(\mathrm{c})(1)$ (2015) (incorporating by reference ANSI Standard Z245.5-2008 or earlier).

${ }_{28}$ See, e.g., 30 CFR $\iint 250.901(\mathrm{a})(4)-(14)$ (2015) (incorporating by reference multiple bulletins and recommended practices of the American Petroleum Institute).

29 E.g., Wendy Wagner, Science in Regulation, Report to the Administrative Conference of the United States 16 (Feb. 18, 2013) (noting the necessary involvement of policy in scientific decisions), http://www.acus.gov/report/science-regulation-final-report.

30 Jon Michaels, Privatization's Pretensions, 77 U. Chi. L. Rev. 717, 718 (2010); see Sharon Dolovich, How Privatization Thinks, in Government by Contract 128, 133 (Jody Freeman \& Martha Minow eds., 2009). 
For example, food inspection programs can benefit by incorporating the experience and expertise already residing in private inspection regimes. As Jody Freeman and others have suggested, private organizations, whether for-profit or not, also can contribute "ingenuity, cost-savings, quality, and diversity[;]"31 and government can learn from private sector experimentalism. ${ }^{32}$ An agency can also leverage its resources, effectively obtaining greater access to private manpower or even financial resources, potentially enabling inspections and approvals for regulated entities. 33

Similarly, by using privately drafted standards, rather than preparing a distinct set of government standards, an agency might save resources, benefit from private expertise, and reduce social costs from duplicative standards. ${ }^{34}$ Agency use of private standards might even improve compliance, if private entities are already likely to be in compliance with private standards, or if compliance with a single set of standards is easier than with multiple sets that are not aligned. Finally, even a less-than-optimal standard may be better than nothing, if the agency would otherwise lack the resources necessary for effective regulation. 35

\section{B Outsourcing's Perils}

Private involvement in public functions presents risks, however, that an individual action might not further the public interest. (Public performance, of course, can have its own pitfalls. ${ }^{36}$ ) First, private entities may face significant conflicts of interest or other tensions with public goals as a result of market

${ }^{31}$ Freeman, supra note 3, at 1289; see also Michaela Tarr Oldfield, Food Safety Governance in the Shadow of Overlapping Networks 2 (2015) (unpublished manuscript) (on file with author) (privatization may minimize regulator "reticence... to revisit rules"); Judith Resnik, Globalization(s), Privatization(s), Constitutionalization and Statization: Icons and Experiences of Sovereignty in the 21st Century, 11(1) INT'L J. ConST. L. 162, 183 (2013) (discussing claims that alternative dispute resolution may be preferable to public adjudication as "more accurate, less expensive, more generative, and more congenial").

32 E.g., Michael Dorf \& Charles Sabel, A Constitution of Democratic Experimentalism, 98 Colum. L. Rev. 267, 287-88 (1998); Kevin Kosar, Cong. Research Serv., RL30533, The Quasi Government: Hybrid Organizations with Both Government and Private Sector Legal Characteristics 11 (2011) (describing a "great strength" of FFDRC's as their ability to promote private-government technology transfers).

33 McAllister, supra note 11, at 386.

34 Current government policy is to encourage agency use of voluntary standards in lieu of "government-unique" standards. National Technology Transfer and Advancement Act of 1995 \$12(d), 15 USC $\$ 272$ note (2012).

35 See generally Emily Bremer, On the Costs of Private Standards in Public Law, 63 Kan. L. Rev. 279, 308 (2015).

$3^{6}$ E.g., John Donahue, supra note 18 , at 61 (noting that government performance of "public missions" may be "less adroit [or] less accountable" than it ought to be). 
incentives or professional culture. ${ }^{37}$ Under current law, private entities, even those engaged in public functions, are often exempt from conflict of interest rules that would apply to public decision makers..$^{3}$ Private entities that certify food as organic or imported food as safe may be paid by those whom they inspect. Competition for inspection work may prompt them to be generous toward customers, overlooking violations in order to get more business. 39 Industry groups, such as the American Petroleum Institute and the American Iron and Steel Institute, draft safety and environmental standards later used by agencies..$^{40}$ Both those entities describe themselves as the voices of their relevant industries; individuals working on standards are generally industry employees..$^{41}$ Practicing specialist physicians may make recommendations on Medicare reimbursement rates for treatments in their own specialty. ${ }^{2}$ Sharon Dolovich has suggested that private contractors' financial interests in prisons may impair their objectivity in giving testimony at an inmate's parole board hearing.43 Agencies also may seek to partner with professional organizations, such as the American Medical Association or the American Society of Mechanical Engineers. The professional culture of these organizations may sometimes be in tension with public goals.44

Second, private entities are often far less accountable to the public for their decisions than a public entity would be. ${ }^{45}$ Private decision making is typically

37 Kathleen Clark, Ethics, Employees and Contractors: Financial Conflicts of Interest In and Out of Government, 62 ALA. L. REv. 961 (2011).

${ }^{3} \quad$ E.g., id. at 967 (focusing particularly on services contracting and "staff augmentation").

39 Timothy Lytton and Lesley McAllister, Oversight in Private Food Safety Auditing: Addressing Auditor Conflict of Interest, 2014 WIS. L. Rev. 289, 294; e.g., Miriam Seifter, Rent-a-Regulator, in Government by Contract 93, 95 (Jody Freeman \& Martha Minow eds., 2009) (noting similar incentives for private certifiers of Massachusetts hazardous waste site cleanups).

$4^{\circ}$ E.g., 24 CFR $\int 3280.4$ (i) (incorporating by reference AISI specification for "Design of ColdFormed Steel Structural Members"); 30 CFR $\$ 250.198(\mathrm{~h})$ (Interior Department Bureau of Safety and Environmental Enforcement, incorporating over 80 American Petroleum Institute standards).

${ }^{41}$ E.g., About AISI, Steelworks (2015), http://www.steel.org/about-aisi/mission.aspx ("AISI serves as the voice of the North American steel industry."); About API, Am. Petrol. Inst. (2015), http://www.api.org/GlobalItems/GlobalHeaderPages/About-API (describing it as a national trade association that "represents all aspects of America's oil and natural gas industry").

42 US Gov't Accountability Office, GaO-15-434, Medicare Physician Payment Rates: Better Data and Greater Transparency Could Improve Accuracy 1 (2015) (noting "potential conflicts of interest" among these physicians).

43 Sharon Dolovich, State Punishment and Private Prisons, 55 Duke L.J. 439, 522-23 (2005); see Resnik, supra note 31, at 183 ("Private prison providers have... lobbied for more detention.").

44 E.g., Mashaw, supra note 8, at 145, 147 (describing tensions between vocational rehabilitation and medical professionals and goals of Social Security disability regime).

45 See id. at 132 (discussing "public law" regimes opposed to "market or social accountability" regimes). 
not subject to the public law devices that make agencies accountable to the public, the White House, or Congress or in the courts. These devices include the centralized regulatory review structure administered by the White House Office of Information and Regulatory Affairs (OIRA), agency authorizing statutes, disclosure requirements under the Freedom of Information Act, the congressional appropriations process, public participation and judicial review requirements under the Administrative Procedure Act, constitutional "state action" doctrine, ${ }^{4}$ as well as the conflict of interest and ethics rules that apply in the public setting.47 Jon Michaels has argued that agencies sometimes involve private entities as a means of avoiding these very obligations. $4^{8}$ And as Gillian Metzger has succinctly observed, the greater the private involvement, even with seemingly governmental functions, very often the less agency involvement, 49 and in turn the less the opportunity to use traditional laws and doctrines of accountability that are keyed to agency action. The same reduction in accountability structures can characterize hybrid public-private institutions..$^{\circ}$ For example, the PCAOB is not an "agency or establishment of the United States Government," ${ }^{11}$ apparently exempting it from the APA and FOIA, among others..$^{2}$

These reduced public law obligations may make private and hybrid entities less accountable for acting to further the agency's mission, 53 unless other

$4^{6}$ See Am. Soc. of Dermatology v. Shalala, 962 F. Supp. 141 (DDC 1996); Int'l Brominated Solvents Ass'n v. Am. Conference of Gov't and Indus. Hygienists, Inc., 393 F. Supp. 2d 1362, 1379-84 (MD Ga. 2005) (despite OSHA's adoption of de facto "exposure levels," refusing to find that ACGIH was "agency" for purposes of APA or that its meetings were subject to FACA); Gillian Metzger, Private Delegations, Due Process and the Duty to Supervise, in Government By Contract 291 (Jody Freeman \& Martha Minow eds., 2009) (discussing state action doctrine); Sarah Lamdan, Sunshine for Sale, Environmental Contractors and the Freedom of Information Act, 15 VT. J. EnvTL. L. 227 (2014) (describing reduced disclosure and public participation requirements); see also 5 USC $\$ 551$ (1) (defining "agency" for purposes of APA); 5 USC $\$ 552$ (f) (defining "agency" for FOIA purposes); 5 USC $\$ 702$ (providing right of review for "agency" action).

47 See Freeman, supra note 3, at 1306.

$4^{8}$ See Michaels, supra note 30; see also Mashaw, supra note 8, at 132 (discussing aspects of "public law" regimes opposed to "market or social accountability" regimes). Cf. S. REP. No. 101-357, supra note 21, at 4948 ("[P] rivate [organic food] certifying agents must agree to hold the Secretary harmless for any failure.").

49 See Metzger, supra note 46, at 291.

50 E.g., A. Michael Froomkin, Reinventing the Government Corporation, 1995 U. ILL. L. Rev. 543,560 .

${ }^{51} 15$ USC $\$ 7211$ (b) (establishing PCAOB as nonprofit corporation subject to the "District of Columbia Nonprofit Corporation Act"); see also O'Connell, supra note 22, at 882.

52 See Free Enter. Fund v. Pub. Co. Accounting Oversight Bd., 130 S. Ct. 3138 (2010); Peter Strauss, On the Difficulties of Generalization, 32 CARDOZO L. Rev. 2255, 2269 (2011).

53 See Mashaw, supra note 8, at ${ }_{13} 6$ ("The problem as many see it is that state power has been added without customary accountability arrangements for the use of that power."); see generally 
constraining regimes, such as market regimes, are sufficiently aligned with the government regime to fill that gap. ${ }^{54}$ The third parties accordingly may pursue different goals and objectives, even diverting public programs and resources to different priorities. 55

Private decision-making may lack legitimacy in the eyes of the public, if the public doubts the private entity's motives. According to Tom Tyler and Yuen Huo, the public may lack "motive-based trust," 56 whether it is in the substance of the private standards or in the quality of inspection decisions. 57 For example, Lesley McAllister reports that food safety groups have been quite "wary of the introduction of third-party auditors into the FDA's regulatory framework." $5^{8}$

A shift to private decision making may also eliminate opportunities for public participation in policy development, such as notice and comment rulemaking. This can both limit information for decision-makers and undermine civic engagement and responsibility since citizens have fewer expressive opportunities. 59 The public may have an increasing sense of distance and disconnection from actions that affect it. ${ }^{60}$

Although private institutions may well deliberate - leading some to suggest that such deliberation "enhances pluralism" 61 - that process may be less open than comparable agency processes, which are formally open to anyone with internet access or access to a public library. Participation in the drafting of private standards, for example, may be limited to organizational members,

Gillian Metzger, The Constitutional Duty to Supervise, 124 YALE L.J. 1836, 1890-93 (2015) (describing a variety of considerations that might be incorporated in "accountability principles," including political accountability, legal accountability, transparency, and opportunities for participation).

54 Mashaw, supra note 8, at 131-34 (discussing range of applicable regimes).

55 E.g., Posner, supra note 5, at 529-32 ("national policy goals can become recast... as third parties redefine programs").

56 Tom Tyler \& Yuen Huo, Trust in the LaW 75 (2002) ("[J]udgments about the motives of [officials] with whom people have personal experiences have more influence on whether people accept the decisions... than do evaluations of the favorability of their outcomes."); Nicholas Parrillo, Against the Profit Motive: The Salary Revolution in AmeriCAN GOVERNMENT 1780-1940, at 35 (2013) (suggesting that Tyler and Ho's findings on motivebased trust apply more generally to whether people are likely to voluntarily comply with legal rules).

57 E.g., Verkuil, supra note 26, at 327 (suggesting that Congress's creation of TSA shows that "sometimes public solutions are widely seen as both more reliable and more credible by the public and Congress").

${ }^{8}$ McAllister, supra note 11 , at 381 .

59 Avihay Dorfman \& Alon Harel, Against Privatization As Such (Hebrew University of Jerusalem Legal Research Paper No. 15-29, 2015), http://papers.ssm.com/sol3/papers.cfm? abstract_id $=2557409$.

6o See generally id. (noting "distanc[ing of] citizens from judgments, decisions, and actions").

61 Minow, supra note 4, at 113 . 
those who pay a fee, or those who can travel..$^{62}$ Even when they are permitted to participate, citizens may not have a high level of trust if they perceive that the private entity has little obligation to respond either to public dialogue or to the leadership of elected officials. ${ }^{63}$ Further, as Michaela Oldfield has demonstrated in the setting of private food regulation, some stakeholders may be overwhelmed by the proliferation of private networks: "decisions affecting stakeholders may be made in any number of places," making it more difficult for stakeholders to discover where key decisions are being made and to participate in all such processes. ${ }^{64}$ Oldfield's research also suggests that stakeholders respect the outcome of private processes if they are included. ${ }^{65}$ Finally, rather than enabling the agency to leverage its resources, an agency's continued, extensive reliance on private standards or actions can result over time in sharply reduced funding to the agency. ${ }^{66}$

In short, private entity involvement in policy decisions raises all the concerns that are focal points for institutional design of the administrative state: ensuring that key governmental decisions are well-reasoned, efficient, functional, democratically responsive, and public-interested.

\section{The Challenges for Agency Supervision of Outsourcing}

To shore up the legitimacy of outsourced government tasks in the face of these challenges, both commentators and the government have turned to agency supervision. ${ }^{67}$ As long as the agency will be reasonably well-resourced, they have often assumed the effectiveness of such supervision. ${ }^{68}$ For example, the

62 See generally Mendelson, supra note 26, at 753-59 (overviewing procedures of private standards development organizations); Oldfield, supra note 31.

63 See Dorfman \& Harel, supra note 59.64 Oldfield, supra note 31, at 27.

${ }^{6}$ Id. at 23 ("[T] stakeholders who are included.").

${ }^{66}$ Cf. Donald F. Kettl, Brookings Inst., Gov't Executive, After the Reforms 38 (Apr. 1998) (describing the Energy Department as a "hollow shell over a vast network of contractors").

${ }_{7}$ The legal framework governing public entities could be broadened to cover private ones, see Nina Mendelson, Six Simple Steps to Increase Contractor Accountability, in Government BY Contract 241 (Jody Freeman \& Martha Minow eds., 2009) (discussing some such changes), but this solution has been criticized as potentially undermining the purported advantages of outsourcing, see Mashaw, supra note 8, at ${ }_{13} 6-37$ (noting that it could be "self-defeating" to impose transparency requirements and that "little may be gained" by requiring "private actors behave just like public officials").

68 Verkuil, supra note 26, at 333 (framing the "crucial .. . question" as whether delegated assignments are clearly defined and "oversight function is publicly performed"); e.g., Jody Freeman \& Martha Minow, Introduction to Government by Contract 1, 4 ("Agency personnel are insufficiently resourced and badly trained for contract management."); Kettl, supra note 1, at 505; McAllister, supra note 11, at 377 ("[T]he agency must have the strength and resources to 
Senate Report accompanying the Organic Foods Production Act of $1990^{69}$ suggested that Agriculture Secretary approval of state organic certification programs would "ensure [consistency]" with statutory goals, and provide a "check on the overall quality and sensibility" of these programs..$^{70}$ The agency itself may claim that its signoff on the private action assures the private action's quality and public-interestedness. For example, in adopting private standards as federal regulations, the Pipeline and Hazardous Materials Safety Administration commented: "PHMSA has the ultimate responsibility to [serve] the best interests of public safety... [w] hen PHMSA believes some aspect of [a private] standard does not meet this [criterion], it will not incorporate [it]." ${ }^{71}$

Public entity supervision may be necessary for formal reasons. Delegation of government power directly to private entities may raise constitutional concerns..$^{72}$ But legislators and the public may also have instrumental reasons to rely on agency supervision. They may count on agency oversight to keep private partnering entities honest - that is, focused on the public interest rather than private profit - as well as to provide public-private action with a patina of legitimacy, and perhaps to ensure the public an opportunity to provide feedback on private decisions.

Supervision can take a range of forms. The agency may be the entity to choose whether to utilize a private standard or to draft its own. ${ }^{73}$ The agency may elect to monitor regulated entity compliance with standards directly or to

ensure that the program is effectively serving regulatory purposes."); Posner supra note 5, at 540 (focusing on capacity and "resource constraints"); Schooner, supra note 14 (suggesting "the federal government must devote more resources to contract administration, management and oversight;" and must minimize "interagency indefinite-delivery contract vehicles"). Metzger does suggest that some measures, mainly greater judicial review opportunities, might satisfy what she characterizes as an agency duty to supervise. Metzger, supra note 53, at 1901, 1903. However, she does not discuss the incentives that supervising officials themselves might face. Jody Freeman also discusses some supplementary mechanisms in the contract implementation setting, see Freeman, supra note 3, at 1325-26 (suggesting private accreditation, information disclosure, and performance audits as possibilities).

69 This Act was enacted as Title XXI of the Food, Agriculture, Conservation, and Trade Act of 1990, Pub. L. No. 101-624 (Oct. 22, 1980).

70 S. Rep. No. 101-357, supra note 21, at 4949.

${ }^{71}$ Pipeline Safety: Incorporation by Reference Update: American Petroleum Institute (API) Standards $5 \mathrm{~L}$ and 1104, 74 Fed. Reg. 170,099 (Apr. 14, 2009).

72 E.g., Dep't of Transp. v. Am. Assoc'n of R.R., 135 S. Ct. 1225 (2015) (rejecting private delegation claim to Amtrak on ground that it is public entity); Carter v. Carter Coal Co., 298 US 238 (1936) (describing "legislative delegation in its most obnoxious form...to private persons whose interests may be and often are adverse to the interests of others in the same business"); see generally Verkuil, supra note 26 at 316 ("[W]hen due process requires a decision maker, it usually requires a public actor.")

73 See National Technology Transfer and Advancement Act of 1995, Pub. L. No. 104-113, 110 Stat. 775 (1996) (codified as amended in scattered sections of 15 USC). 
enlist third-party certifiers. ${ }^{74}$ Agencies may supervise the private activity or be entitled to give or withhold final, formal approval of a private decision. Supervision might also consist of monitoring compliance with agency-drafted contract specifications. ${ }^{75}$ PCAOB rules are subject to Securities and Exchange Commission approval, ${ }^{76}$ as are the rules of the self-regulatory stock exchanges. ${ }^{77}$ When an agency incorporates a private standard by reference, the agency must first publish a notice of proposed rule and then, through a final rule, act to incorporate a private standard into federal rules. ${ }^{7}$ In its supervision of private certifying of the safety of imported food, the FDA may either accept "certification" from "accredited entities" of imported foods or else perform inspections directly.79 The Agriculture Department relies upon private and state entities to certify foods as meeting USDA's organic standards, but it can revoke the accreditation of organic food certifying entities. And in making each such supervisory decision, the agency's actions are typically subject to the usual public law framework. So the agency may, in reaching its decision, utilize procedures that would apply if the agency were acting alone, such as a public comment process in rulemaking. ${ }^{80}$ Finally, a decision to revoke certification or to adopt a rule could be subject to judicial review.

But supervision of private activities faces some distinctive obstacles that should raise concerns about whether agency oversight can be depended on to assure the quality and public-interestedness of private decisions. As detailed below, obstacles include incentives that may prompt an agency to defer to a private decision even when it is not fully consistent with the agency's statutory mission; reduced external accountability of the agency for its oversight decisions; and reduced usefulness of the internal decision-guiding procedures on which agencies normally rely.

74 E.g., McAllister, supra note 11, at 297 (noting that, of eight third-party verification schemes, "Congress directed agencies to use third-party verification in four... [and i]n the others, agencies chose third-party verification without specific Congressional authorization").

75 E.g., Mashaw, supra note 8, at 139-51 (describing contracted-out aspects of social security disability benefits program); Schooner, supra note 14, at 9-15 (noting potential challenges for contractual incentives).

$7^{6}$ See Sarbanes-Oxley Act $\$ 107(\mathrm{~b})(2)-(3), 15$ USC $\$ 7217$ (2012) (conditioning PCAOB rule effectiveness on "prior approval of the Commission").

77 E.g., 15 USC $\$ 78 \mathrm{~s}(\mathrm{~b})(\mathrm{1})$ (providing for SEC approval following notice and comment).

$7^{8}$ 1 CFR $\$ 51.5$ (amendments effective Jan. 6, 2015).

7921 USC $\$ 381(q),(q)(4)$ (2012). The FDA is expected to inspect roughly 10 percent of foreign facilities itself after five years of implementation of the Food Safety and Modernization Act; the rest will be handled by the cooperative system. See Tacy K. Hass, New Governance: Can UserPromulgated Certification Schemes Provide Safer, Higher Quality Food?, 68 Food \& Drug L.J. 77,80 (2013).

8० Agencies may take comment before approving a self-regulatory agency's standard, for example. 


\section{Agency Incentives and Capacity}

Assume at the outset that agency officials are public-interested and aim to implement their authorizing statute faithfully (as opposed, say, to having their motivations distorted by industry capture). Agencies nonetheless may lack adequate expertise and information to review outsourced private decisions. Although outsourcing can sometimes enable an agency to leverage its resources, reliance on private entities can also aggravate expertise constraints within agencies. Effective supervision requires expertise within the agency. ${ }^{81}$ Even if an agency possesses the relevant expertise when it begins to utilize or build on private frameworks or standards, repeated outsourcing of policy decisions may result in an agency downsizing its own expert staff. ${ }^{82}$ An agency may also lose the opportunity for institutional experience that typically accompanies implementation. ${ }^{8}$

Consider recent events at the Pipeline and Hazardous Materials Safety Administration. After much outsourcing of private standards drafting, the agency was faced with a legislative requirement for free online availability of all incorporated private standards. Among these was the privately drafted Boiler and Pressure Vessel Code, which covers everything from residential "water heaters to equipment used in nuclear power plants." ${ }_{4}$ Although the agency was only interested in a few important sections of those standards, it could not reach agreement for free availability with the drafting organization, the American Society of Mechanical Engineers. This put the agency over a barrel since, as Emily Bremer has explained, it had "neither the technical expertise nor the resources to [replace them]," having relied on the private standards for decades. ${ }^{8}$ This cautionary tale raises serious concerns about whether the agency nonetheless could possess sufficient technical expertise to review the privately drafted standards in the first place.

Agency supervision is also plagued by inadequate information, since private implementing entities are likely to possess far greater control over the relevant information than the agency. Consider the food safety program's system for private auditing of imported foods. The FDA is proposing to recognize accreditation bodies for these auditors and is asserting a power to withdraw an

${ }^{81}$ See Mashaw, supra note 8, at 138 ("If public bureaucracies do not do, they will not learn; and this trained incapacity will [undermine their ability to supervise]); see also Kelman, supra note 7 , at 175 (suggesting that key factor is not the ability to "do," but instead "subject matter expertise" on contract goals).

82 Mashaw, supra note 8 , at 138 ("recapturing lost capacities may turn out to be very difficult"); Freeman \& Minow, supra note 68, at 5.

83 McAllister, supra note 20, at 30-31 (suggesting agencies learn from assessing compliance).

84 Bremer, supra note 35 , at $328 . \quad 85$ Id. 
individual auditor's accreditation for inadequate performance. The difficulty, as Timothy Lytton and Lesley McAllister suggest, is that identifying auditing failures depends significantly on "linking foodborne illness to particular food safety failures." 86 This, in turn, requires the agency to gather information either on foodborne illness or on the quality of auditing. But the more that initial responsibility is shifted to private entities to make decisions, whether that is standards development or inspection of particular facilities, the more effort likely will be required for an agency to gather the information needed for monitoring. ${ }^{87}$

Even apart from expertise and information limitations, even the most publicinterested agency official may face strong incentives to utilize less-than-ideal private actions in her implementation of public frameworks, rather than monitoring closely. Reliance on private activity in a particular case may save the agency significant resources that could be deployed elsewhere. ${ }^{88}$ Because agency use of private standards or inspection regimes often does not involve government contracting, the agency may not need to expend funds to take advantage of the private framework. Beyond saving its own resources, an agency may save additional costs or avoid legal burdens. For example, an agency using private standards can avoid the required report for an agency adopting a "government-unique" standard instead of a private voluntary standard. ${ }^{89}$

Meanwhile, despite the outsourcing, the official can take credit for achieving regulatory goals. For example, although the USDA does not inspect organic farms, farms use a "USDA Organic" label. The agency makes no mention of private certifying entities when it announces: "USDA has strengthened its oversight of organic products, using methods such as inspections and residue testing to ensure the integrity of organic products from farm to market." 90

${ }^{86}$ Lytton \& McAllister, supra note 39, at 334. See generally McAllister, supra note 11, at 406 (noting that some standards can prevent information flow to an agency or to the public); Posner, supra note 5, at 527 ("Information on [third party] performance... is also difficult to ascertain ... audits and field monitoring... can be expensive...").

87 See Seifter, supra note 39, at 106 (noting that "[a]bsent tips" state agency possesses only the information it gathers itself).

88 McAllister, supra note 11, at 295 (discussing “leveraging private regulation”). E.g., Mendelson, supra note 26 , at 784 .

89 See National Technology Transfer and Advancement Act of 1995, Pub. L. No. 104-113, 110 Stat. 775 (1996) (codified as amended in scattered sections of 15 USC); see also Office of Mgmt. \& Budget, Exec. Office of the President, OMB Circular No. A-119 (revised 2016). The reporting requirement further raises the cost of not using a private standard; it might also prompt an agency to adopt a standard unchanged, since an adjusted private standard might be criticized as duplicative.

90 Organic Agriculture, USDA, http://www.usda.gov/wps/portal/usda/usdahome?contentidonly= true\&contentid=organic-agriculture.html (last visited Sept. 2, 2015). 
The citizen must dig deep into the agency's website to discover that the certifying agent is a "private, foreign, or State entity that has been accredited by the USDA."91 Similarly, PHMSA's Mission \& Goals webpage states that the agency's mission is to protect people and the environment from the risks of hazardous materials transportation, by "establish[ing] national policy, set[ting] and enforc[ing] standards," and so on. In taking credit for protecting the public, the agency makes no mention of the numerous private standards that it incorporates by reference. $9^{22}$

An agency choice to rely upon private efforts bears some resemblance to the congressional delegation of responsibilities to administrative agencies. Congress has faced criticism for "claim[ing] credit for the benefits which a regulatory statute promises yet escap[ing] the blame for the burdens it will impose ... "93 Agencies, too, may be tempted to claim victory (or at least effectiveness) by virtue of having standards or an enforcement program in place, while avoiding blame for less than optimal performance. In part because disclosure laws such as the Freedom of Information Act do not apply when a private entity is the actor, the details of the private standards or private inspection regimes may not be open to view.94 Further, although agencies are subject to disclosure regimes, an agency need not, when it takes credit for solving a problem, simultaneously explain its reliance on industry or other private efforts. The challenge of figuring out exactly who is making key government decisions may be even greater when the job is being done by numerous private entities, because that will disperse the relevant information even further.

An agency will also save other sorts of costs when it relies on private actions. Officials may expect a higher rate of regulated entity compliance with private frameworks or standards, when regulated entities are involved in their devising. Such frameworks or standards might better track regulated entity

91 Id.

92 That PHMSA relies relatively heavily on private standards can be discerned mainly by digging deeper into the website. E.g., Standards Incorporated by Reference, PHMSA, http://www.phmsa .dot.gov/portal/site/PHMSA/menuitem.6f23687cf7boobof2ze4c6962dgc8789/?vgnextoid= d 5 af714769382310VgnVCM1ooooorecb7898RCRD\&vgnextchannel=fob8a535eac17110Vgn VCM1ooooogedo7898RCRD\&vgnextfmt=print (last visited Sept. 2, 2015) ("PHMSA currently incorporates by reference... all or parts of more than 6o [privately drafted] standards and specifications."). Roughly half of PHMSA's reported "latest rulemakings" appear to be incorporation of private standards, though one must open each Federal Register notice to see this. Standards and Rulemakings, PHMSA, http://www.phmsa.dot.gov/pipeline/regs (last visited Sept. 2, 2015).

93 David Schoenbrod, Power Without Responsibility: How Congress Abuses the People Through Delegation 11 (1993).

94 Restrictions on public access to standards or other information on the private actions can impede agency accountability to political overseers still further. See Mendelson, supra note 26. 
preferences or utilize currently adopted technologies, rather than forcing new technology (or locking in old technology). ${ }^{95}$ Less attractively, complying with these standards may be easier to the extent they simply demand less of regulated entities. This reduces the agency's monitoring and enforcement costs. And to the extent regulated entities are well represented in Congress or the White House, $9^{6}$ agency use of their decisions reduce the agency's oversight costs by reducing complaints to those institutions. All these benefits might well tempt even a public-interested agency official to rely on a private decision that does not properly implement statutory goals.

If the agency can be understood as "captured" by the entities it regulates, that may give it even more reason to utilize regulated-entity-drafted materials or frameworks. An agency interested in expanding its own power, the scenario Michaels discusses, may be further tempted by outsourcing as a means of evading legal limits. Substantial federal outsourcing of military and security functions, for example, has been necessitated by "politically unpopular but empirically unjustified Congressional troop caps."97

\section{Limitations on Judicial Review of Agency Oversight}

Under normal circumstances, we depend significantly on external accountability mechanisms, such as judicial review, to ensure that an agency is properly implementing its statutory mission. But judicial review may be less useful to address inadequate agency supervision of outsourced activity. First, there may not be a specific agency action to review, if an agency has simply failed to revoke an accreditation for an inadequate inspection. In addition, no framework may impose a sufficiently discrete, mandatory supervising obligation on the agency that would give rise to a right to review..$^{8}$ (Without outsourcing, an outright agency failure to inspect might not be reviewable, but an inadequate

95 E.g., Mendelson, supra note 26, at 785 (describing US firms pushing for international optics standards that would favor American technological preferences).

${ }^{6}$ E.g., Nicholas Bagley, Response, Agency Hygiene, 89 Tex. L. Rev 1, 5 (2010); see also Richard W. Murphy, Essay, Enhancing the Role of Public Interest Organizations in Rulemaking Via Pre-Notice Transparency, 47 WAKe Forest L. Rev. 681, 687 n.33 (2012) ("A common criticism of OIRA review is that it ... generally favors regulated interests.").

97 Steven Schooner, Book Review, The Invisible Soldiers, Parameters 44(3), Autumn 2014, at $152-153$.

$9^{8}$ Metzger, for example, has suggested that the duty to supervise could be recognized as a constitutional one, enforced through judicial review. See generally Metzger, supra note 53. However, challenging an agency failure to inspect on these grounds might be challenging. E.g., Norton v. Southern Utah Wilderness Alliance, 542 US 55 (2004) (holding that agency inaction is cognizable APA "action" for which judicial review is available only if action is discrete and mandatory). 
inspection would be.) Even when agency supervision results in a cognizable action, as with the incorporation of privately drafted standards, there may be significant obstacles. As I have discussed elsewhere, for example, the lack of public access to privately drafted standards is likely to hinder affected citizens from invoking agency procedures, bringing a lawsuit challenging the agency's action, or contacting a member of Congress. 99

Moreover, even if there is a cognizable agency action, such as a flawed accreditation decision, a potential plaintiff could face particular difficulties establishing standing, because of the difficulty of connecting risks or harm to the individual with the agency's decision. In September 2015, the Centers for Disease Control and the Food and Drug Administration finally traced a summertime salmonella outbreak to imported Mexican cucumbers. ${ }^{100}$ But research could not uncover whether this facility or the cucumbers had been inspected by accredited private inspectors at all, let alone whether closer FDA supervision of the inspectors might have made a difference to the risks faced by a plaintiff. Even with a documented outbreak, obtaining judicial review would be very difficult. Establishing standing to challenge FDA inspection practices could be difficult even in the absence of outsourcing, but the additional layer of outsourcing could impose daunting proof problems upon a potential plaintiff.

\section{Internal Procedure}

Internal procedures that can guide or constrain an agency's action may also be less functional when an agency is supervising outsourced functions. Such procedures would ordinarily be useful in at least two ways: first, for the agency to gather information, and second, to constrain an agency to act in a reasoned fashion that furthers statutory goals, even if an agency official's motivation is less than ideal. But in an outsourcing context, these procedures may be less effective, because key aspects of the decision have occurred in the private setting, prior to the agency's involvement.

For one example, conflict of interest rules that might constrain selfinterested decisions by government officials will likely offer little help when an agency reviews private decisions of individuals exempt from such rules. Government officials typically lack the information necessary to properly

99 See generally Mendelson, supra note 26.

100 E.g., Multistate Outbreak of Salmonella Poona Infections Linked to Imported Cucumbers, Centers for Disease Control \& Prevention (Nov. 19, 2015, 11:45 AM), http://www.cdc .gov/salmonella/poona-o9-15/index.html. 
evaluate such decisions. The Government Accountability Office recognized this difficulty when it assessed collaborative research arrangements among the National Institutes of Health, the Environmental Protection Agency, and the American Chemistry Council regarding impacts of environmental chemicals. The agencies believed that this arrangement could help them effectively leverage public resources; both sought public input on research topics and peer review on the research proposals. Nonetheless, the GAO charged that the agencies' lack of careful attention to the private conflict of interest issues raised real concerns, potentially calling into question the "quality and independence of federally funded research."101

Rulemaking procedures will also be less effective when the agency action is to select an already drafted private standard. Under APA Section 553, courts have required agencies to disclose the data relied upon to effectuate the statutory opportunity to comment. ${ }^{102}$ Further, the rulemaking process is formally open to the public. Even under typical circumstances, this process is not perfect. It has been criticized as unbalanced, favoring regulated entities, ${ }^{103}$ and less useful when agencies have precommitted to policies. But the rulemaking process is understood to provide public participation, as well as some feedback on the agency's data, reasoning process, and proposal, ${ }^{104}$ and possibly even on public values. ${ }^{105}$

Where the agency is adopting an already drafted private standard, however, the agency is far more likely to have pre-committed to the rule. Moreover, private entities may provide only minimal access to their data during their own deliberations, and the agencies may not disclose it at all during rulemaking. ${ }^{106}$ The frequent lack of meaningful free public access to the private standards' text further hinders the public's ability to identify coverage, workability, or other issues. Agencies also have reduced the time for public participation down to a minimum in view of earlier private process, even if that process is

\footnotetext{
101 Gov't Accountability Office, GAO-05-191, Federal Research: NiH and EPA Need to Improve Conflict of Interest Reviews for Research Arrangements with Private Sector Entities 20 (2005).

102 United States v. Nova Scotia Food Prods. Corp., 568 F.2d 240, 252 (2d Cir. 1977).

103 E.g., Murphy, supra note 96, at 689-91; Jennifer Shkabatur, Transparency With(out) Accountability: Open Government in the United States, 31 Yale L. \& Pol'y Rev. 79, 86 (2012) (noting imbalance in rulemaking); Wendy E. Wagner, Administrative Law, Filter Failure, and Information Capture, 59 DUKE L.J. 1321, 1382, 1386 (2010).

104 Cynthia Farina, Mary Newhart \& Josiah Heidt, Rulemaking v. Democracy: Judging and Nudging Public Participation that Counts, 2 Mich. J. Envtl. \& Admin. L. 123, 130 (2012).

105 Nina Mendelson, Should Mass Comments Count?, 2 Mich. J. Envtl. \& Admin. L. 173 (2012).

106 See Mendelson, supra note 26 (noting probable APA violations).
} 
not fully open ${ }^{107}$ In short, the lack of access and time is likely to undermine the public's ability to provide useful "written data, views, or arguments"108 to the agency. Compared with the relatively well-represented regulated entities, other members of the public are likely to be cut out of the earlier private process and provided only a limited opportunity to participate in the agency's process. Finally, consider that an agency typically faces particular pressure not to adopt a distinctive government standard when a private one is available. A public comment would have to overcome a high hurdle before it might prompt an agency to adopt a modified voluntary standard or reject it outright. At least one organization has argued that agencies should - if they are adopting private consensus standards at all - adopt those standards verbatim. ${ }^{109}$ In short, because the real work happens before agency rulemaking begins, rulemaking procedures provide less useful input and less opportunity for public participation.

OIRA also generally subjects agency rules to close evaluation under the Executive Order 12,866 regulatory review process. But with an outsourced rule, regulatory review may be weaker or nonexistent. OIRA appears to impose fewer requirements when an agency utilizes industry standards in lieu of drafting its own standards. Consider a June 2015 proposed rule of the Department of the Interior's Bureau of Safety and Environmental Enforcement for cranes mounted on oil drilling platforms in the Outer Continental Shelf. The rule proposes to incorporate by reference an American Petroleum Institute design and construction standard. ${ }^{110}$ As the agency explained, since these standards are developed and written by "industry experts and approved by the industry itself," the agency assumes industry is already complying, and the standards can be included "in the baseline" when considering the regulation's potential economic impacts. ${ }^{111}$ With no new economic costs expected, therefore, the agency published the proposed rule without regulatory analysis or OIRA review. ${ }^{112}$ The agency was thus able to avoid considering whether alternative

107 E.g., Proposed Rules: Oil and Gas and Sulphur Operations in the Outer Continental Shelf Update of Incorporated Cranes Standard, 8o Fed. Reg. 34,113, 34,114 (June 15, 2015) ("This proposed rule provides 30-days for public comment because the Seventh Edition of API Spec ${ }_{2} \mathrm{C}$ (which was extensively reviewed and discussed during the API standard-setting consensus process) has been in effect for well over two years; thus the relevant industries are already familiar with [it]...."). The agency's document provided no details of the API process.

108 See 5 USC $\int 553$ (c) (2012).

109 The Fertilizer Institute, Comment Letter on Proposed Revisions to OMB Circular A-119, at 3 (May 12, 2014), http://www.regulations.gov/\#!documentDetail;D=OMB-2014-0001-0035.

11 See Proposed Rules: Oil and Gas and Sulphur Operations in the Outer Continental Shelf Update of Incorporated Cranes Standard, 8o Fed. Reg. 34,113 (June 15, 2015).

${ }^{111}$ Id. at 34,117. ${ }^{112}$ Id. 
rules (including more stringent ones) might have greater net benefits or more appropriately implement statutory commands. ${ }^{113}$

One indicator of the obstacles to effective agency oversight of outsourced decisions might be the relatively low change rates. Agencies rarely revoke a private delegation, override a private entity's decision, or modify a privately drafted standard when incorporating it into a federal regulation. For example, the Health and Human Services Centers for Medicare and Medicaid has adopted, nine out of ten times, the American Medical Association's recommendations for Medicare physician payments. ${ }^{114}$ As I have described elsewhere, when agencies incorporate privately drafted standards by reference, they almost never modify them, instead adopting them wholesale. ${ }^{115}$ For another example, the Agriculture Department has revoked accreditation to only two domestic organic food certifiers in the multi-year history of the program. ${ }^{116}$

Of course, this information is very limited. A USDA decision to reject an accreditation request altogether may not be publicly reported, as with an agency decision not to utilize a private standard at all. Or perhaps private organizations and standards simply are functioning well. Even so, these examples strongly suggest the need for more systematic examination of structures of agency supervision.

\section{A FEW CONCLUDING THOUGHTS REGARDING REFORM}

Agencies rely on private actions and institutions in a wide array of settings. We must pay more conscious attention to the design of agency supervision of public-private collaboration, though no single design will likely address all settings. The following is a very preliminary, brief sketch of factors that might be considered in designing this supervision.

113 To the extent industry is not complying with the API's standard because, say, it is overly costly, one might reach different conclusions. Perhaps permitting the agency to avoid regulatory impact analysis simply lowers the obstacles to the agency issuing a costly rule.

114 See Nicholas Bagley, Bedside Bureaucrats: Why Medicare Reform Hasn't Worked, 101 Geo. L. J. 519, 543 (2013); Uwe E. Reinhardt, The Little-Known Decision-Makers for Medicare Physicians Fees, N.Y. Times Economix Blog (Dec. 10, 2010, 6:00 AM), http://economix.blogs .nytimes.com/2010/12/10/the-little-known-decision-makers-for-medicare-physicans-fees; e.g., Am. Soc'y of Dermatology v. Shalala, 962 F. Supp. 141, 144-45 (DDC 1996).

115 Mendelson, supra note 26, at 783 (searching identified eighteen agency rules, out of thousands, where agency used a private rule with modifications).

116 See List of Surrendered, Suspended, and Revoked Certifiers, USDA (July 1, 2015), http://www.ams.usda.gov/sites/default/files/media/OrganicSusRevACAso7012015.pdf. Three foreign entities are also listed as suspended. Nearly 80 organizations are accredited. See Organic Certifying Agents List by State (US only), USDA (Jan. 8, 2016), http://www.ams.usda .gov/sites/default/files/media/OrganicCertifyingAgentsbyState.pdf. 


\section{A Adequacy of Agency Expertise, Resources, and Information}

As numerous scholars have noted, adequate financial resources are essential, though not sufficient, for effective agency supervision of outsourced functions. ${ }^{117}$ Expertise is also required, whether from qualified civil servants or from a peer review or advisory committee process. The agency would, however, need to ensure that peer review-type processes are functioning properly. ${ }^{118}$ Finally, agencies must be able to obtain the requisite information. In the case of privately drafted standards, for example, an agency needs assurance of access to the private data supporting the standards; for inspection, development of performance metrics would undoubtedly be helpful for evaluating private entity performance. ${ }^{119}$

\section{B Process}

Agencies might consider supplementing their procedures to compensate for potential shortcomings or imbalances in the private decision making. If an agency faces less-than-ideal incentives to defer to the private decision and is thus unlikely to self-regulate, Congress might require agency procedures to increase the agency's incentive to make a well-supported, reasoned decision that furthers the statutory mission.

Realistically, unless Congress so requires, an agency is unlikely to condition acceptance of a private decision on the private entity's use of a particular internal process. ${ }^{120}$ Private organizational procedures can vary substantially, making development of consistent procedural criteria difficult, but more importantly, an agency imposing conditions might be perceived as directly regulating the private organizations. Thus far, agencies have avoided any appearance of micromanaging a private institutional "partner."121 For

${ }^{117}$ E.g., McAllister, supra note 11, at 377-79.

118 E.g., Gov't Accountability Office, GaO-05-191, Federal Research: NiH and EPA NeEd to Improve Conflict of Interest Reviews for Research Arrangements with Private Sector Entities (2005) (finding peer review processes inadequate to address potential conflicts of interest in outsourced research).

${ }^{119}$ GAO has suggested the development of "performance measures." E.g., Gov'T AcCounTABILity Office, GAO-15-183, Food Safety: Additional Actions Needed to Help FDA's Foreign Offices Ensure Safety of Imported Food 19 (2015) (recommending that the FDA develop performance measures to assess its foreign offices' contributions to food safety).

${ }^{120}$ Of course, an agency's continuing refusal to accept certain standards could be understood as an implicit condition. Compare Freeman, supra note 3, at 1315 (suggesting Congress could extend process requirements to contractors).

${ }^{221}$ Cf. Mashaw, supra note 8, at 144 (noting SSA's difficulty in controlling state "partners" "[b]ecause of intergovernmental politics"). 
example, OMB Circular A-119, which encourages agencies to use voluntary consensus standards, even encouraging agency officials to participate in private standards development, also emphasizes the need for agency officials to participate "on an equal basis with other members, consistent with the procedures of standards bodies." 122

Even if agencies do not condition acceptance of private decisions upon any particular process, however, agencies could evaluate - or Congress could require agencies to evaluate - process as a factor in assessing a private decision and deciding whether additional agency processes are appropriate. An agency could evaluate whether the private process would develop relevant information and whether all affected interests (not just regulated entities) have a meaningful opportunity to participate. In response, an agency could extend its own comment period or disclose information to the public to facilitate an effective comment process. An agency concerned about the private organization's neutrality or voting rules could take steps to ensure that a full range of stakeholders will be informed and engaged. ${ }^{123}$ Such steps might also address procedural proliferation, in which stakeholders can be overwhelmed by multiple private processes and unable to meaningfully participate in each such process. ${ }^{124}$

The agency might also develop relatively explicit safeguards or procedures to address conflict of interest or other bias problems - or consider, under some circumstances, refusing to endorse the private decision.

Thus far, however, when agencies choose to utilize private standards, Federal Register notices have betrayed little consideration of private process quality. In a recent incorporation by reference of American Petroleum Institute standards for "toughness criteria" for oil pipelines, for example, the Pipeline and Hazardous Materials Safety Administration did not discuss, at either the proposed or final rulemaking stage, any aspect of API's procedures, such as the membership or openness of its standards drafting committees or that the organization's members come entirely from the petroleum industry. ${ }^{125}$

122 Office of Mgmt. \& Budget, Exec. Office of the President, OMb Circular No. A-119, 6d (revised 2016) ("What is the Policy for Federal Participation in Standards Bodies?; Do agency representatives participate equally with other members?"); see id. at 6a ("agency representatives should avoid the practice or the appearance of undue influence”)

123 Cf. Murphy, supra note 96.

124 See supra text accompanying notes 64-66 (discussing Oldfield research).

125 E.g., Pipeline Safety: Incorporation by Reference Update: American Petroleum Institute (API) Standards 5L and 1104, 74 Fed. Reg. 170,099 (Apr. 14, 2009) (containing no discussion of API 


\section{Considering Agency Incentives to Outsource and Outside Accountability}

This chapter has noted that even public-regarding agency officials may be tempted to overrely on outsourcing to claim credit as well as to leverage resources. Potential overreliance could be checked somewhat through internal process structures, greater transparency, or judicial review. These mechanisms could increase agency accountability for such decisions. As discussed above, however, judicial review of the agency's supervisory choices (or lack thereof) often may not be a realistic possibility. Responsive measures might include removing impediments to judicial review, such as ensuring meaningful free access to privately drafted standards or providing for some sort of petition right to revoke an accreditation, with judicial review available of an agency's denial of the petition.

Other measures could increase the likelihood that agency oversight of these private activities is meaningful. Agencies could be required to develop metrics of program success or to facilitate more systematic oversight by outside organizations. ${ }^{126}$ These measures might increase agency accountability for properly approving private decisions, although they could also be costly. ${ }^{127}$ In addition to the FDA auditing the accreditation of inspectors of imported food, for example, perhaps a separate government board could be responsible for regular review of selected inspections, reporting overall on the success of the program. Such an arrangement might also be adapted to other settings, such as review of agency adoption or incorporation of private standards. For example, the GAO is currently tasked with conducting a triennial review of the SEC's oversight of the Financial Industry Regulatory Authority (FINRA). ${ }^{128}$ This sort of review could bring greater transparency to the agency supervision process. We might attempt also to increase agency self-discipline

standards development process or members); see API Overview and Mission, Am. Petrol. INST. (2015), http://www.api.org/globalitems/globalheaderpages/about-api/api-overview (noting industry membership). Although standards committees are open to "representatives of government agencies and academia," travel is required. See Standards Committee Information, Am. Petrol. InSt. (2015), http://www.api.org/publications-standards-and-statistics/ standards/committee-information.

126 Cf. U.S. Gov't Accountability Office, GAO-12-165, SEC Oversight of FinRA 6 (2012) (discussing recommendation that the SEC develop "a set of metrics to assess SRO regulatory effectiveness").

127 Cf. Freeman, supra note 3, at 1285 (noting that it will be "costly and burdensome to extend public norms to private actors").

${ }_{128}$ See Dodd-Frank Wall Street Reform and Consumer Protection Act $\$ 964,15$ USC \& 78d9 note (2012); U.S. Gov't Accountability Office, GAO-12-165, SEC Oversight of FINRA (2012). 
by requiring agencies to provide more reasoned explanations for decisions approving particular private actions (or, perhaps, for declining a request to revoke a particular accreditation). ${ }^{129}$

In short, public-private collaboration has the potential, eventually, to dominate regulation and implementation of government programs. But simply placing an agency in an oversight role is not sufficient to ensure that private activities will be properly incorporated into public governance. To assess the odds that supervision will be effective, it is critical to look more deeply at the structures and incentives that may impact agency supervision of particular outsourced activities. We should pay greater attention to how these activities are supervised in the hope of ensuring that all activity done in the name of the government, no matter by whom, appropriately serves the public interest. What seems clear is that the presence of a supervising agency, without more, may not be a panacea.

129 Cf. Sidney Shapiro \& Richard W. Murphy, Constraining White House Political Control of Agency Rulemaking Through the Duty of Reasoned Explanation, 48 U.C. Davis L. REv. 1457, 1463 (2015) (" $[\mathrm{W}] \mathrm{e}$ propose that courts and litigants deploy petitions for rulemaking to force agencies to provide prompt explanations for indefinite delays connected with centralized review."). 